\section{Kidney transplantation with donors in severe acute kidney injury. Should we use these organs? Retrospective Case Series}

Transplante renal com doadores em lesão renal aguda severa. Devemos utilizar esses órgãos? Série de casos retrospectiva

\section{Authors}

Guilherme Palhares Aversa Santos ${ }^{1}$ iD Luis Gustavo Modelli de Andrade ${ }^{1}$ (D) Mariana Farina Valiatti ${ }^{1}$ (D)

Mariana Moraes Contti ${ }^{10}$

Hong Si Nga' ${ }^{1 D}$

Henrique Mochida Takase ${ }^{1}$ (D)

${ }^{1}$ Universidade Estadual Paulista, Faculdade de Medicina de Botucatu, Departamento de Clínica Médica, Botucatu, SP, Brasil.

Submitted on: 12/24/2018. Approved on: 06/17/2019.

Correspondence to:

Guilherme Palhares Aversa Santos E-mail: guipalhares.santos@gmail.com DOI: 10.1590/2175-8239-JBN-2018-0264

\section{Abstract}

Introduction: The number of incident and prevalent patients on dialysis has increased, as well as the number of candidates for renal transplantation in Brazil, without a proportional increase in the number of organ donors. The use of expanded kidneys, as to renal function, may be an alternative to increase the supply of organs. Objective: to discuss the feasibility of using expanded kidneys for renal function, which are in severe acute renal injury. Methods: All cases of renal transplantation of deceased donors performed at the Hospital das Clínicas de Botucatu of UNESP, from January 2010 to June 2018, totaling 732 cases were evaluated. Cases with final donor creatinine greater than $6 \mathrm{mg} / \mathrm{dL}$ were selected. Results: four patients were selected, of whom all donors were in severe acute kidney injury (AKI). These donors presented rhabdomyolysis as a probable cause of severe AKI, were young, with no comorbidities and had decreased urinary volume in the last 24 hours. The clinical evolution of all the recipients was satisfactory, with a glomerular filtration rate after transplantation ranging from 48 to $98 \mathrm{~mL} / \mathrm{min} / 1.73 \mathrm{~m}^{2}$. Conclusion: this series of cases shows the possibility of using renal donors in severe AKI, provided the following are respected: donor age, rhabdomyolysis as the cause of AKI, and implantation-favorable biopsy findings. Additional studies with better designs, larger numbers of patients and longer follow-up times are needed.

Keywords: Kidney Transplantation; Tissue Donors; Delayed Graft Function; Acute Kidney Injury.

\section{Resumo}

Introdução: $\mathrm{O}$ número de pacientes incidentes e prevalentes em diálise tem aumentado, assim como o número de candidatos ao transplante renal no Brasil, sem um aumento proporcional do número de doadores de órgãos. $\mathrm{O}$ uso de rins expandidos, quanto à função renal, pode ser uma alternativa para aumentar a oferta de órgãos. Objetivo: discutir a viabilidade do uso de rins expandidos quanto à função renal, que estejam em lesão renal aguda severa. Métodos: foram avaliados todos os casos de transplante renal de doador falecido realizados no Hospital das Clínicas de Botucatu da UNESP, de janeiro de 2010 a junho de 2018, totalizando 732 casos. Selecionou-se os casos com creatinina final do doador maior do que $6 \mathrm{mg} /$ dL. Resultados: quatro pacientes foram selecionados, dos quais todos os doadores estavam em lesão renal aguda (LRA) severa. Esses doadores apresentavam rabdomiólise como provável causa de LRA severa, eram jovens, sem comorbidades e apresentavam diminuição de volume urinário nas últimas 24 horas. A evolução clínica de todos os receptores foi satisfatória, com taxa de filtração glomerular após o transplante variando entre 48 a $98 \mathrm{~mL} / \mathrm{min} / 1,73 \mathrm{~m}^{2}$. Conclusão: essa série de casos mostra a possibilidade de utilização de doadores renais em LRA severa, desde que respeitadas as condições seguintes: idade do doador, rabdomiólise como causa de LRA e achados de biópsia favoráveis à implantação. Estudos adicionais com melhores desenhos, maior número de pacientes e maiores tempos de seguimento são necessários.

Palavras-chave: Transplante de Rim; Doadores de Tecidos; Função Retardada do Enxerto; Lesão Renal Aguda. 


\section{INTRODUCTION}

In recent years, the number of incident and prevalent dialysis patients has increased, as has the number of renal transplant candidates in Brazil ${ }^{1}$ without a proportional increase in the number of organ donors. The use of renal donors with expanded criteria is a measure that may help in solving this problem and has been increasingly adopted. ${ }^{2}$ Kidneys of donors with acute kidney injury (AKI) - KDIGO III, considered expanded kidneys as to renal function, are frequently discarded $^{3}$ but its use may contribute to a greater supply of organs.

The objective of this series of cases was to discuss the feasibility of expanded kidneys with severe acute renal injury being used for renal function.

\section{Method}

This is an observational, retrospective, case-series study. All cases of renal transplantation performed at the Hospital das Clínicas of UNESP from January 2010 to June 2018 were reviewed. Our goal was to evaluate the most severe and more challenging cases of AKI donors for the transplantation under the clinical viewpoint, in this eight-year period, we selected all patients transplanted from a deceased donor with a final creatinine level greater than $6 \mathrm{mg} /$ dL. This creatinine cutoff value was based on the retrospective study carried out by Heilman et al., in which the maximum final creatinine of donors with AKI was $6.29 \mathrm{mg} / \mathrm{dL}^{4}$

\section{Results}

A total of 732 transplant recipients from deceased donors were found in the period, of which 4 fulfilled the selection criteria. Clinical and laboratory data are described below.

Case 1. Female, 44 years old, having granulomatosis with polyangeitis as baseline disease, peritoneal dialysis for 2 years and 11 months, residual diuresis of $600 \mathrm{~mL}$, antibody reactivity panel (ARP) of 0 . Donor: female, 37 years old, cause of death, traumatic HSA after severe head injury, without comorbidities, three days of hospitalization in Intensive Care Unit (ICU), using Clavulanic acid to treat an infective pulmonary focus and noradrenaline $1.8 \mathrm{mcg} / \mathrm{kg} /$ min, diuresis of $300 \mathrm{~mL}$ in the past 24 hours, initial creatinine of $1.1 \mathrm{mg} / \mathrm{dL}$, final creatinine of $7.4 \mathrm{mg} /$ dL, CPK of 8,688 U/L, Kidney Donor Profile Index
(KDPI) of $46 \%$. Uptake renal biopsy with signs of ATN. Cold ischemia duration (CID) of 23 hours and 30 minutes, induction therapy with methylprednisolone $500 \mathrm{mg}$ and thymoglobulin $3 \mathrm{mg} / \mathrm{kg}$ and maintenance therapy with tacrolimus, everolimus and prednisone. The transplantation occurred without problems, with no urologic or vascular complications. The patient had delayed graft function (DGF) in the postoperative period, with progressive improvement of nitrogenous waste and urinary output from the second week after transplantation. She was discharged from the hospital on the 30th postoperative day. Currently, with two years and eight months of transplantation, she has creatinine of $1.0 \mathrm{mg} / \mathrm{dL}$ and TFG (by CKD-epi) of $67 \mathrm{~mL} / \mathrm{min} / 1.73 \mathrm{~m}^{2}$.

Case 2. Male, 38 years old, unknown baseline disease, without residual diuresis, in renal replacement therapy for 9 years and 5 months, under hemodialysis, ARP of 0 . The donor is the same as that of Case 1 patient. TIF of 25 hours and 5 minutes, induction therapy with methylprednisolone $500 \mathrm{mg}$ and thymoglobulin $3 \mathrm{mg} / \mathrm{kg}$ and maintenance therapy with tacrolimus, everolimus and prednisone. Transplantation occurred without intercurrences, with no urologic or vascular complications. He developed DGF, with partial improvement of the waste and urine output from the 14th day of hospitalization. On account of prolonged DGF, he was biopsied at the 18th postoperative day, with pathology compatible with ATN. He was discharged in the $28^{\text {th }}$ postoperative day. C urrently, with the same time of transplantation as the patient of case 1, he has a GFR of $58 \mathrm{~mL} / \mathrm{min} / 1.73 \mathrm{~m}^{2}$.

Case 3. Female, 52 years old, unknown baseline disease, on hemodialysis for 4 years and 11 months, residual diuresis of $500 \mathrm{~mL}$, ARP of $34 \%$. The donor, A 43-year-old male smoker, had acute subdural hematoma after traumatic head injury as the cause of death, two days of ICU, using noradrenaline $0.8 \mathrm{mcg} / \mathrm{kg} / \mathrm{minute}$, vasopressin $6 \mathrm{IU} /$ hour, diuresis in the last $24 \mathrm{~h}$ of $120 \mathrm{~mL}$, initial creatinine of $1.1 \mathrm{mg} / \mathrm{dL}$ and final creatinine of 12.2 $\mathrm{mg} / \mathrm{dL}$, CPK of $58,124 \mathrm{U} / \mathrm{L}, 54 \%$ KDPI. The uptake renal biopsy presented ATN. TIF of 22 hours and 46 minutes, induction therapy with methylprednisolone $500 \mathrm{mg}$ and thymoglobulin $4.5 \mathrm{mg} /$ $\mathrm{kg}$ (divided into $1.5 \mathrm{mg} / \mathrm{kg}$ initiated on anesthetic induction, and then $1 \mathrm{mg} / \mathrm{kg}$ for 3 more days) and therapy with tacrolimus, mycophenolate and 
prednisone. Surgery occurred without complications, with no vascular or urologic complications. Patient evolved with DGF, being biopsied in the $13^{\text {th }}$ postoperative due to prolonged DGF, histopathologically compatible with ATN. There was an increase in urine output and progressive waste formation from the 21 st day of hospitalization. He presented several infectious intercurrences (UTI, esophageal moniliasis, cytomegalovirus infection); he was discharged from the hospital in the 46th postoperative day. Currently, after 5 months and 13 days of transplantation, he has a creatinine level of $0.8 \mathrm{mg} / \mathrm{dL}$ and GFR of $98 \mathrm{~mL} / \mathrm{min} / 1.73 \mathrm{~m}^{2}$.

Case 4. Male, 35 years, unknown baseline disease for 1 year and 5 months, residual diuresis of $1000 \mathrm{~mL}$, ARP of 0. Male donor, 35 years old, traumatic HI as cause of death, chronic alcoholic, 6 days of ICU, diuresis of $350 \mathrm{~mL}$ in the last 24 hours using noradrenalin $0.16 \mathrm{mcg} / \mathrm{kg} / \mathrm{min}$, initial creatinine of $1.1 \mathrm{mg} / \mathrm{dL}$ and final of $6.5 \mathrm{mg} /$ $\mathrm{dL}, \mathrm{CPK}$ of $11,922 \mathrm{IU} / \mathrm{L}, 33 \%$ KDPI. Uptake renal biopsy ATN-compatible. TIF of $20 \mathrm{~h} 33 \mathrm{~min}-$ utes. Induction therapy with $500 \mathrm{mg}$ of methylprednisolone and thymoglobulin $4.5 \mathrm{mg} / \mathrm{kg}$, and maintenance with tacrolimus, mycophenolate and prednisone. Surgery occurred without complications, with no urologic or vascular complications. He evolved with DGF, underwent a biopsy on the 15 th postoperative day with ATN findings. As of the $21^{\text {st }}$ postoperative day, there was a renal function improvement, and he was discharged on the $29^{\text {th }}$ POD. Currently, after 6 months and 12 days of transplantation, he has creatinine of $1.8 \mathrm{mg} / \mathrm{dL}$ and GFR of $48 \mathrm{~mL} / \mathrm{min} / 1.73 \mathrm{~m}^{2}$.

Table 1 depicts clinical and laboratory data from donors and recipients.

\section{Discussion}

In this retrospective series of four cases, we evaluated the experience of a tertiary care hospital with kidney transplantation from donors in KDIGO III AKI and with final creatinine higher than $6 \mathrm{mg} / \mathrm{dL}$.

All donors in this series are considered to be of the standard category according to the classic criteria of United Network for Organ Sharing (UNOS) ${ }^{5}$ expanded donors, but we can consider them to be borderline in renal function. Donors in this series were young, were on KDIGO III AKI and had renal biopsy of the ATN uptake (with no significant histological changes in the glomerular, tubule-interstitial and vascular compartments). The most likely renal insults were ischemic and nephrotoxic by rhabdomyolysis, with good prospects for recovery.

Regarding renal donors with altered creatinine, Kayler et al., in a retrospective study using the American transplant registry system, showed that, for standard criteria donors, the increase in serum creatinine in the donation was not associated with a decrease in survival graft, despite a higher percentage of DGF. In addition, for standard donors, the presence of final creatinine greater than $2 \mathrm{mg} / \mathrm{dL}$ increased the risk of organ rejection 7 fold, ${ }^{3}$ showing an underuse of these organs.

Boffa et al., In a retrospective study, analyzed the UK transplant registration system between 2003 and 2013. The presence of AKI in the donor increased the likelihood of kidney discarding, and the longer the stage of AKI, the greater the risk of not using the organ. In kidney donors with AKIN III AKI, the risk of organ rejection increased from 3 to 20 fold. ${ }^{6}$ There was little difference in graft survival comparing kidneys from donors with AKI and those without AKI (91\% vs. $89 \%, p=0.02)$. However, when compared with the

Table 1. Clinical and Laboratory Data from Donors and Recipients

\begin{tabular}{lcccccccccc}
\hline & $\operatorname{Cr}(1)$ & $\operatorname{Cr}(2)$ & $\operatorname{Cr}(3)$ & $\operatorname{Cr}(4)$ & $\operatorname{Cr}(7)$ & $\begin{array}{c}\text { Uptake } \\
\text { biopsy }\end{array}$ & $\begin{array}{c}\text { Donor } \\
\text { age }\end{array}$ & $\begin{array}{c}\text { C.P.K. } \\
(\mathrm{UI} / \mathrm{mL})\end{array}$ & $\begin{array}{c}\text { ARP } \\
(\%)\end{array}$ & $\begin{array}{c}\text { UO } \\
(\mathrm{mL})\end{array}$ \\
\hline Case 1 & 6.3 & 6.4 & 4.4 & 2 & 1.1 & ATN & 37 & 8688 & 0 & 300 \\
Case 2 & 8.6 & 13.7 & 9.1 & 5.1 & 1.6 & ATN & 37 & 8688 & 0 & 300 \\
Case 3 & 8.3 & 3.5 & 6.1 & 1.8 & 0.8 & ATN & 43 & 58124 & 34 & 120 \\
Case 4 & 9.8 & 15.6 & 7.7 & 4.4 & 2.2 & ATN & 35 & 11922 & 0 & 350 \\
\hline
\end{tabular}

Note: C.P.K: creatine phosphokinase. $\operatorname{Cr}(1)$ : $\mathrm{cr}$ in the $1^{\text {st }}$ week, $\operatorname{Cr}(2): \mathrm{cr}$ in the $2 \mathrm{nd}$ week, $\mathrm{Cr}(3): \mathrm{cr}$ in the $3^{\text {rd }}$ week, $\operatorname{Cr}(4): \mathrm{cr}$ in the $4^{\text {th }}$ week, $\mathrm{Cr}(7): \mathrm{cr}$ in the $7^{\text {th }}$. UO: Donor's urinary output in the past $24 \mathrm{~h}$. ARP: antibodies reaction panel. ATN: Acute Tubular Necrosis. 
survival of patients in the queue for transplantation or on dialysis, this small difference does not have clinical relevance. In this study, there was an association between donors with a higher stage of AKI (AKIN III) and a higher rate of non-functioning primary organs; however, the number of donors with AKIN III AKI was small in the sample studied.

Zheng et al., in a systematic review and metaanalysis of 2018 with 14 cohort studies, involving 15,345 donors, did not find a significant difference in relation to graft survival and in relation to primary non-functioning organs, when comparing kidney recipients from AKI donors with those without AKI. ${ }^{7}$ Graft survival was assessed within one to ten years after transplantation. In addition, GFR and episodes of acute rejection were similar between the groups. In patients with AKI, there was longer hospital stay and a higher incidence of DGF.

Heilman and colleagues retrospectively assessed the outcomes of 162 kidney recipients from AKI donors over a period of about 9 years. Of these recipients, 139 received kidneys considered standard according to UNOS. It is noteworthy that among these standard kidney donors, $50 \%$ were oligoanuric, $71 \%$ with AKIN III stage AKI and 21\% required renal replacement therapy. The final maximum creatinine in this group of standard donors in AKI was $6.29 \mathrm{mg} /$ dL. However, with the exception of DGF, which was higher in the group of patients with AKI, there was no difference in the incidence of acute rejection and graft survival in one year compared to patients who transplanted in the same period and received kidneys from donors who were not in AKI. ${ }^{4}$

Donor age, one of the criteria for considering an offered kidney as borderline, is well established as a condition that requires histological evaluation of the kidney to be implanted. ${ }^{5,8}$ This characteristic is also important to consider in cases of renal donation whose donor is in AKI, the age of the donor, rather than the final creatinine value has a greater association with outcome and worsening renal function in 6 months. ${ }^{9}$

The histological assessment of the AKI kidneys is fundamental, as it shows their viability before implantation. The absence or discrete histological lesions correlate with good graft survival in one year, favoring the use of the organ offered; while the presence of moderate to severe lesions correlates with poor graft survival, making transplantation unwise. ${ }^{10,11}$ Kyler and colleagues reviewed 597 renal donor biopsies performed between 1987 and 2006; arteriosclerosis, or moderate arteriolosclerosis, defined as a decrease in vascular lumen equal to or greater than $25 \%$, were independently associated with poorer graft survival at one, three, and five years for both standard and marginal donors. ${ }^{10}$

Regarding the clinical course of AKI, these three donors were in a clear phase with oliguria, and the possibility of acute renal support could be considered, except for the condition of brain death. Such a clinical evolution could have led to organ rejection in many transplantation centers.

Tomita et al. Reported their experience with eight cardiac arrest donors who presented KDIGO III AKI, with creatinine greater than $10 \mathrm{mg} / \mathrm{dL}$, prior to renal uptake. However, unlike the present series of cases, at the time of collection, patients already had adequate urine output and recovery of renal function. Most of these patients had good renal function after the first month of transplantation, as occurred with our patients, and adequate long-term graft survival. ${ }^{12}$

It is possible to argue that all three donors in this study had AKI for rhabdomyolysis. In a retrospective observational study carried out by Chen et al., they analyzed 30 patients diagnosed with KDIGO III AKI kidneys during rhabdomyolysis, compared to 90 patients who received standard kidneys, and they reported that there was no statistical difference in relation to creatinine and GFR at months 2, 6, 12 and 24; there was also no difference in the incidence of rejection, ${ }^{13}$ showing good graft function in the long term.

All patients reported in this series had DGF, as expected, since the percentage of graft delay in renal donors with AKI is high. $6,7,8,9$ The main risk factor and probable etiological factor for DGF is the KDIGO III AKI diagnosis validity prior to donation. Other risk factors include the long dialysis time prior to transplantation in the first case and the 25-hour CID in the third case.

The results and outcomes of this series of cases should be considered according to the nature of this study, that is, with limited power of association and generalization. Studies with more patients and longer follow-up are necessary.

\section{Conclusion}

This case series shows the possibility of using KDIGO III AKI donor kidneys with high final creatinine; 
observing the donor age conditions, kidney biopsy without histological lesions or discrete lesions and ischemic AKI with rabdomyolysis. Further studies, with better designs and larger numbers of patients are needed in order to assess the true possibility of using these kidneys.

\section{AUthors' CONTRIBUTIONS}

Guilherme Palhares Aversa Santos, Luis Gustavo Modelli de Andrade, Mariana Farina Valiatti, Mariana Moraes Contti, Hong Si Nga, Henrique Mochida Takase contributed substantially to the conception or design of the study; collection, analysis, or interpretation of data; writing or critical review of the manuscript; and final approval of the version to be published.

\section{CONFLICT OF INTEREST}

The authors declare that they have no conflict of interest related to the publication of this manuscript.

\section{REFERÊNCIAS}

1. Sociedade Brasileira de Nefrologia (SBN). Censo da Sociedade Brasileira de Nefrologia 2017. São Paulo: Sociedade Brasileira de Nefrologia; 2018 [cited 2018 Oct 20]. Available from: https://sbn.org.br/o-censo-2017-foi-publicado-confira/

2. Querard AH, Le Borgne F, Dion A, Giral M, Mourad G, Garrigue $\mathrm{V}$, et al. Propensity score-based comparison of the graft failure risk between kidney transplant recipients of standard and expanded criteria donor grafts: Toward increasing the pool of marginal donors. Am J Transplant 2018;18:1151-7. DOI: https://doi.org/10.1111/ajt.14651

3. Kayler LK, Garzon P, Magliocca J, Fujita S, Kim RD, Hemming AW, et al. Outcomes and utilization of kidneys from deceased donors with acute kidney injury. Am J Transplant 2009;9:36773. DOI: https://doi.org/10.1111/j.1600-6143.2008.02505.x
4. Heilman RL, Smith ML, Kurian SM, Huskey J, Batra RK, Chakkera HA, et al. Transplanting Kidneys from Deceased Donors With Severe Acute Kidney Injury. Am J Transplant 2015;15:2143-51. DOI: https://doi.org/10.1111/ajt.13260

5. Metzger RA, Delmonico FL, Feng S, Port FK, Wynn JJ, Merion RM. Expanded criteria donors for kidney transplantation. Am J Transplant 2003;3:114-25. DOI: https://doi.org/10.1034/ j.1600-6143.3.s4.11.x

6. Boffa C, van de Leemkolk F, Curnow E, Homan van der Heide J, Gilbert J, Sharples E, et al. Transplantation of Kidneys From Donors With Acute Kidney Injury: Friend or Foe? Am J Transplant 2017;17:411-9. PMID: 27428556 DOI: https://doi. org/10.1111/ajt.13966

7. Zheng YT, Chen CB, Yuan XP, Wang CX. Impact of acute kidney injury in donorson renal graft survival: a systematic review and Meta-Analysis. Ren Fail 2018;40:649-56. DOI: https://doi. org/10.1080/0886022X.2018.1535982

8. Remuzzi G, Cravedi P, Perna A, Dimitrov BD, Turturro M, Locatelli G, et al.; Dual Kidney Transplant Group. Long-term outcome of renal transplantation from older donors. N Engl J Med 2006;354:343-52. PMID: 16436766 DOI: https://doi. org/10.1056/NEJMoa052891

9. Si Nga H, Takase HM, Bravin AM, Garcia PD, Contti MM, Kojima CA, et al. Good Outcomes in Kidney Transplantation With Deceased Donor With Acute Kidney Injury: Donor's Age and Not Acute Kidney Injury Predicts Graft Function. Transplant Proc 2016;48:2262-6. PMID: 27742275 DOI: https://doi. org/10.1016/j.transproceed.2016.06.004

10. Kayler LK, Mohanka R, Basu A, Shapiro R, Randhawa PS. Correlation of histologic findings on preimplant biopsy with kidney graft survival. Transpl Int 2008;21:892-8. DOI: https:// doi.org/10.1111/j.1432-2277.2008.00681.x

11. Ugarte R, Kraus E, Montgomery RA, Burdick JF, Ratner L, Haas $\mathrm{M}$, et al. Excellent outcomes after transplantation of deceased donor kidneys with high terminal creatinine and mild pathologic lesions. Transplantation 2005;80:794-800. PMID: 16210967 DOI: https://doi.org/10.1097/01.TP.0000173801.33878.BF

12. Tomita Y, Iwadoh K, Ogawa Y, Miki K, Kai K, Sannomiya A, et al. Single Graft Utilization From Donors With Severe Acute Kidney Injury After Circulatory Death. Transplant Direct 2018;4:e355. DOI: https://doi.org/10.1097/ TXD.0000000000000768

13. Chen CB, Zheng YT, Zhou J, Han M, Wang XP, Yuan XP, et al. Kidney transplantation from donors with rhabdomyolysis and acute renal failure. Clin Transplant 2017;31. DOI: https:// doi.org/10.1111/ctr.13021 